\title{
Business Process Improvement Using Business Process Modelling Notation (BPMN) at Fika Crispy Mushroom
}

\author{
${ }^{1} Y$ D P Negara* \\ ${ }^{1}$ Department of Informatics Engineering, \\ University of Trunojoyo Madura, Indonesia \\ Email : yudha.putra@trunojoyo.ac.id ${ }^{1}$,
}

\author{
A F Doni ${ }^{2}$ \\ ${ }^{2}$ Department of Informatics Engineering \\ University of Trunojoyo Madura, Indonesia \\ doni.fatah@trunojoyo.co.id ${ }^{2}$
}

\begin{abstract}
Nobody has sold or produced crispy mushrooms in the Tanjung Bumi region. For this reason, the producer wants to produce crispy mushrooms because the making or processing is quite easy and here the production does not only sell crispy mushrooms (finished goods), the production also sells oyster mushrooms (raw materials). And the goal of the production of producing crispy mushrooms is because of these crispy mushrooms, including quality snacks that have benefits that are good for the body and also without cholesterol. The problem arises when the company grows, that is, there is no written business process that is the benchmark in running the business, so the decisions made can change based on conditions causing ineffective and inefficient business processes. Therefore, it requires an analysis of business process improvement. The first step is modelling the Fika Crispy mushrooms process using the Business Process Model and Notation (BPMN), the second step is doing Process Validation, Time Validation, and Resource Validation in business processes. Then determine the streamlining used to improve the effectiveness and efficiency of business processes.
\end{abstract}

Keywords: Bpmn, Business process, Fika Crispy

\section{Introduction}

Nobody has sold or produced crispy mushrooms in the Tanjung Bumi region. For this reason, the producers want to produce crispy mushrooms because the making or processing is quite easy and here the production does not only sell crispy mushrooms (finished goods), the production also sells oyster mushrooms (raw materials). And the goal of the production of producing this crispy mushroom is because this crispy mushroom is a quality snack that has good benefits for the body and also without cholesterol. which is not appropriate, takes too long so that new goods cannot be processed immediately, or the delivery time of the goods from the warehouse to the store is not in accordance with the owner's expectations. From the problems that have been explained, further analysis is needed to determine the business processes and activities that have the potential to cause these problems, so that improvements can be made and also produce business process recommendations, with the hope that they can be more efficient in carrying out existing business process activities.

Several previous studies have used Business Process Modelling Notation (BPMN) as a tool for analysing business processes [1]-[9]. Streamlining tools can evaluate business processes carried out by companies and provide business process recommendations to companies that are more efficient [10], [11], [20], [12]-[19].

Business Process Improvement (BPI) is used to analyse Fika Crispy Mushroom business processes by modelling business processes using Business Process Modelling Notation (BPMN), then analysing the activities of each activity at BPMN and providing recommendations by considering 12 streamlining tools at BPI.

Based on the facts that have been explained, the writer is interested in conducting research to find a better Fika Crispy Mushroom business process, by modelling and analysing the Fika Crispy Mushroom business process using Business Process Improvement (BPI). Therefore, the author raised the title Business Process Improvement Using Business Process Modelling Notation (BPMN) at Fika Crispy Mushroom

\section{Literature Review}

\subsection{Business Process Improvement}

Business Process Improvement is a tool that is used systematically developed to help 
companies or organizations to improve business process operations. BPI provides methods that assist in streamlining business processes, while ensuring internal and external customers of the organization get better output. The main objective of Business Process Improvement is to ensure that organizations have business processes that minimize delays that are easy to use, giving the organization a competitive advantage. Phase on BPI is Organizing for improvement. In this first phase aims to determine which process will be updated. The next phase is the process of definition that illustrates the process flowchart and the analysis process. The third phase is Streamlining which aims to improve the efficiency, efficiency and adaptability of

\section{Methods}

This study refers to the reference structure with the research flow depicted in Figure 1.

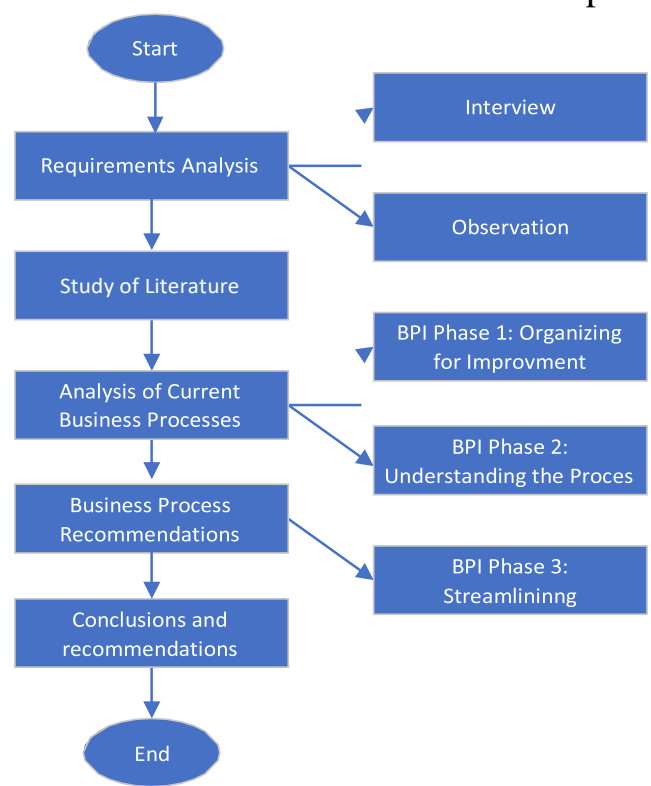

Figure 1. Research Flow Chart

The reason for choosing a method using BPI and BPMN is because there are several references that have already used the method and can improve the company's business processes.

\subsection{Requirements Analysis}

In the needs analysis phase is divided into two, Interview and Observation. Interviews were conducted by asking questions to respondents and owners of Fika Crispy Mushrooms. The question is business processes, engagement processes, business processes, business needs, business challenges, and future goals of Fika Crispy Mushrooms. The observation in this study is observing the object. Objects observed are the results of interviews that require deeper recovery of information, such as studying documents relating to each business process, observing the detail of time needed in each process, observing the behaviour of each actor in bringing the business process out and, the data needed in every process. business processes. The fourth phase is Measurement and controls is the application of business processes that are regularly updated and controlled. The fifth phase is Continuous Improvement which aims to complete the process of continuous improvement.

\subsection{Business Process Model and Notation (BPMN)}

Business Process Model and Notation (BPMN) is a business process modelling standard that provides graphic business process notation in business process schemes. BPMN describes organizations with graphical notation to communicate in a standard way 
Modeller tool and evaluating business processes.

\subsection{Business Process Recommendations}

At this stage produces recommendations for business process improvement, the results will be modelled with BPMN, comparing the results of current business process simulations with business process recommendations.

\subsection{Conclusions and recommendations}

At this stage, conclusions are drawn from research conducted for the purpose of providing the final picture of all this research.

\section{Result}

\subsection{Analysis of Current Business Processes}

Data from interviews and observations obtained data needed to carry out this research, the authors conducted an interview with $\mathrm{Mr}$. Yoyok as the owner of Fris Crispy Mushrooms. The author also observes directly, namely by directly observing the business processes that run on Fika Crispy Mushrooms.

Organizational Identification is to manage improvement. Organizational identification is explained about the organizational environment, organizational structure, including the duties and responsibilities of stakeholders, as well as what business processes are in Fika Crispy Mushroom, obtained by the author from interviews and references from documents belonging to Fika Crispy Mushrooms.

\subsection{Organizational Scope}

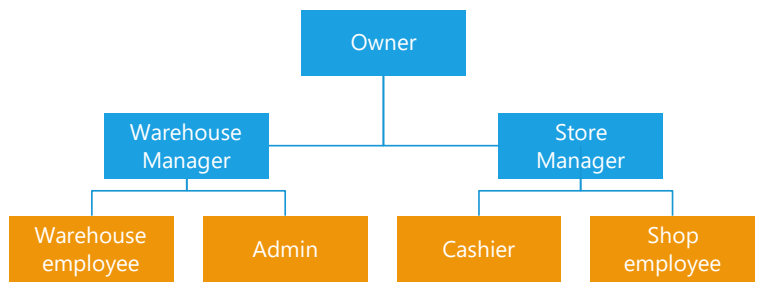

Figure 2. Research Flow Chart

\subsection{Identification of the Needs and} Expectations of the Crispy Mushroom Fika At this stage, the author explains the needs and expectations of Fika Crispy for business process improvement. To find out, the authors conducted interviews with Fris Crispy Mushroom Owners, Admin, and Store Managers. At the end of the Fika Crispy
Mushroom owner, the business processes at Fika Crispy Mushroom are more efficient and efficient and increasingly lead To the expectations of the admin, the business processes carried out can be carried out quickly. Store manager wants business processes can be done quickly, so that customer service becomes faster.

Table 1. Actor's Expectations

\begin{tabular}{ll}
\hline No & Expectations \\
\hline 1 & $\begin{array}{l}\text { The business process at Fika Crispy mushroom is even more efficient and effective } \\
\text { and even bigger }\end{array}$ \\
2 & Fast business processes without problems \\
3 & The process that was done did not arise a problem \\
4 & There is no problem in the process that is run \\
5 & Profit increases \\
6 & More organized process \\
\hline
\end{tabular}

\subsection{Identification of Current Business Processes}

The next step is to identify the current business process carried out by Fika Crispy Mushroom based on its components, namely: description, actors involved, business process models, and an explanation of the business process flow. Next will be identified business processes with the critical success factor (CSF) method, the business processes include: 1) Inventory of goods 2) Ordering. 


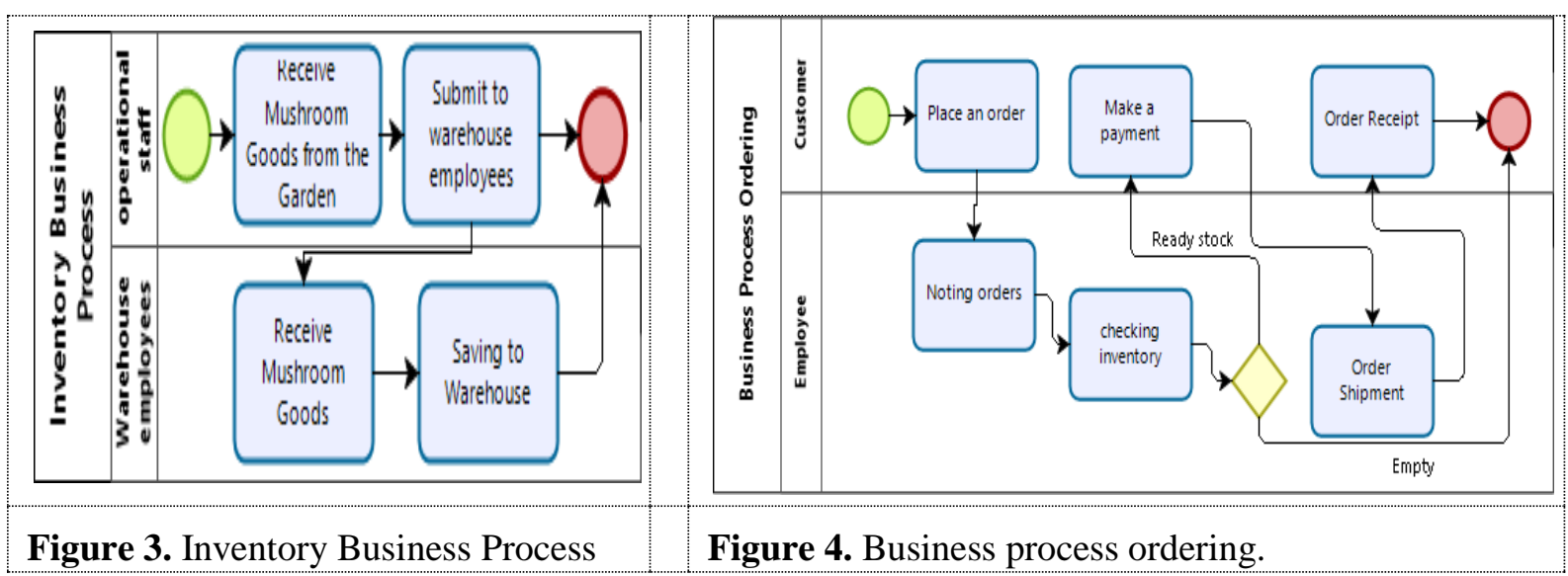

4.5. Analysis of proposed business processes

From the identification of business processes that have been carried out before, will identify the problems that exist in the business process of inventory transactions, and ordering in table 2.

Table 2. Actor's expectations

\begin{tabular}{lll}
\hline Business process & Problem & Code \\
\hline Availability of goods & Item not available & 1 \\
Availability of goods & Damaged goods & 2 \\
Booking & Order cancelled & 3 \\
Booking & Delay of order arrival & 4 \\
Booking & Miss Communication & 5 \\
\hline
\end{tabular}

Langkah selanjutnya adalah memberikan rekomendasi usulan proses bisnis yang akan diperbaiki menggunakan metode Proses Business Improvement (BPI) untuk memberikan perbaikan proses bisnis yang digambarkan pada table 3 dan 4. streamlining tools pada BPI adalah pilihan yang mudah dan dapat memberikan pengaruh besar pada proses dalam memperbaiki proses bisnis. Pada table 5 adalah hasil simulasi yang dilakukan pada model proses bisnis yang diusulkan

Table 3. Business Process Inventory Improvement

\begin{tabular}{llll}
\hline No & $\begin{array}{l}\text { Problem } \\
\text { Code }\end{array}$ & Repair technique & Information \\
\hline 1 & 1 & $\begin{array}{l}\text { Upgrade item } \\
\text { availability } \\
\text { Storage upgrade }\end{array}$ & $\begin{array}{l}\text { This improvement will focus on cultivating the fungus for } \\
\text { even better } \\
\text { This improvement will focus on storing the fungus so that } \\
\text { the fungus is safer and stays good }\end{array}$ \\
2 & 2 & &
\end{tabular}

Table 4. Improved Order Business Process

\begin{tabular}{llll}
\hline No & $\begin{array}{l}\text { Problem } \\
\text { Code }\end{array}$ & Repair technique & Information \\
\hline 1 & 3 & $\begin{array}{l}\text { Better service } \\
\text { Set the delivery } \\
\text { schedule } \\
\text { Communication } \\
\text { tool upgrade }\end{array}$ & $\begin{array}{l}\text { This improvement will focus on better service } \\
\text { In this repair, it will focus on the delivery schedule so there } \\
\text { are no problems } \\
\text { This improvement will focus on better communication } \\
\text { tools }\end{array}$ \\
\hline
\end{tabular}

Table 5. Time Simulation Results

\begin{tabular}{ll}
\hline No & Time (minutes) \\
\cline { 1 - 1 } Inventory & 20 \\
Booking & 60
\end{tabular}

\section{Conclusion}

The supply and rural business process is a business process model in Fika Crispy
Mushroom that has a Critical Success Factor (CSF) value. The current business supply process takes 20 minutes, with less goods 
available. The ordering business process now takes 60 minutes. With problems at the time of shipment and order. Proposed business processes after an evaluation of the Business Process Improvement (BPI), resulted in the business process of the proposed inventory transaction being $60 \%$ faster, the business process of ordering the proposed transaction faster $70 \%$.

\section{REFERENCES}

[1] P. Wiśniewski, K. Kluza, and A. Ligęza, "An approach to participatory business process modeling: BPMN model generation using constraint programming and graph composition," Appl. Sci., vol. 8, no. 9, 2018, doi: 10.3390/app8091482.

[2] P. Bocciarelli, A. D'Ambrogio, A. Giglio, and E. Paglia, "BPMN-Based Business Process Modeling and Simulation," in Proceedings - Winter Simulation Conference, 2019, vol. 2019- December, pp. 1439-1453, doi: 10.1109/WSC40007.2019.9004960.

[3] S. Boukelkoul and R. Maamri, "Optimal model transformation of BPMN to DEVS," in Proceedings of IEEE/ACS International Conference on Computer Systems and Applications, AICCSA, 2016, vol. 2016-July, doi: 10.1109/AICCSA.2015.7507115.

[4] T. Weilkiens, C. Weiss, A. Grass, and K. N. Duggen, "Modeling Business Processes Using BPMN," in OCEB 2 Certification Guide, 2016, pp. 93-147. O. Fakorede, P. Davies, and D. Newell, "Using Business Process Modelling to Improve Student Recruitment in UK Higher Education," pp. 1-12.

[6] P. Wiśniewski, K. Kluza, and A. Ligęza, "An approach to participatory business process modeling: BPMN model generation using constraint programming and graph composition," Appl. Sci., vol. 8, no. 9, 2018, doi: 10.3390/app8091428.

[7] M. Sbayou, Y. Bouanan, G. Zacharewicz, and J. Francois, "Agent based modeling architecture

with BPMN and DEVS network," 29th Eur. Model. Simul. Symp. EMSS 2017, Held Int. Multidiscip. Model. Simul. Multiconference, I3M 2017, pp. 391398, 2017.

[8] K. Chand and M. Ramachandran, "Complexity evaluation with business process modeling and simulation," COMPLEXIS 2018 - Proc. 3rd Int. Conf. Complexity, Futur. Inf. Syst. Risk, vol. 2018-March, no. Complexis 2018, pp. 136-141, 2018, doi: $10.5220 / 0006790501360141$.

[9] F. Amalina and Y. Handayati, "Business Process Analysis and Improvement in Selling Process Using Business Process Modelling Notation (BPMN) at Locarvest," KnE Soc. Sci., vol. 2020, pp. 459-477, 2020, doi: 10.18502/kss.v4i6.6619.

[10] N. Ismail, A. Komari, and S. Rahayuningsih, "Analisa Proses Bisnis Satuan Layanan dan Administrasi di Kantor Perwakilan Bank Indonesia Kediri Menggunakan Metode Business Process Improvement (BPI)," JATI UNIK J. Ilm. Tek. dan Manaj. Ind., vol. 2, no. 1, p. 28, 2019, doi: 10.30737/jatiunik.v2i1.372.

[11] R. I. R. Raditya Rizky Putra, Nanang Yudi Setiawan, "Analisis dan Evaluasi Proses Bisnis Menggunakan Business Process Improvement (BPI) pada UB Guest House," J. Pengemb. Teknol. Inf. dan Ilmu Komput. Univ. Brawijaya, vol. 2, no. 9, pp. 3193-3201, 2018.

[12] N. Rizqi, U. Hidayati, T. A. Ramadhan, and M. A. Yaqin, "Simulasi Proses Bisnis Pondok Pesantren Menggunakan Anylogic Berdasarkan Metode Business Process Improvement (BPI)," Jurasik (Jurnal Ris. Sist. Inf. dan Tek. Inform., vol. 5, no. $1, \quad$ p. 138, 2020, doi: 10.30645/jurasik.v5i1.178.

[13] S. D. Larasati, S. A. Wicaksono, and N. H. Wardani, "Perbaikan Proses Bisnis Menggunakan Metode Business Process Improvement (BPI) ( Studi Pada Bagian Riset Pemasaran dan Pusat,"

J. Pengemb. Teknol. Inf. dan Ilmu Komput. Univ. Brawijaya, vol. 1, no. 11, pp. 1425-1432, 2017.

[14] S. Dwiartono, N. Y. Setiawan, and A. Rachmadi, "Rekomendasi Dan Perbaikan Proses Bisnis Menggunakan Business Process Improvement Pada PT. Trivia Nusantara," J. Pengemb. Teknol. Inf. Dan Ilmu Komput. Univ. Brawijaya, vol. 3, no. 2, pp. 13421348, 2019.

[15] H. S. Sadzali, N. Y. Setiawan, and I. Aknuranda, "Evaluasi dan Perbaikan Proses Bisnis Menggunakan Business Process Improvement (BPI) (Studi 
Kasus : Dinas Pengendalian Penduduk , Keluarga Berencana, Pemberdayaan Perempuan dan Perlindungan Anak Kabupaten Kediri )," vol. 2, no. 11, pp. 5718-5725, 2018.

[16] R. A. Nurfitria, "ANALISIS PROSES BISNIS SISTEM INFORMASI ADMINISTRASI SKRIPSI DENGAN PENDEKATAN BUSINESS PROCESS IMPROVEMENT (Studi Kasus pada Program Studi Ilmu Administrasi Bisnis Fakultas Ilmu Administrasi Universitas Brawijaya)," J. Adm. Bisnis, vol. 64, no. 1, pp. 8491, 2018.

[17] A. G. Waluyo, I. Aknuranda, and N. Y. Setiawan, "Analisis Proses Bisnis Pada Toko Buku Galuh Menggunakan Business Process Improvement Framework," J. Pengemb. Teknol. Inf. dan Ilmu Komput. Univ. Brawijaya, vol. 2, no. 12, pp. 7568-7574, 2018.

[18] T. Susanto, D. Pramono, and N. Y. Setiawan, "Analisis dan Perbaikan Proses Bisnis Menggunakan Metode Business Process Improvement (BPI) Framework (Studi Kasus Bidang Pengembangan Produk Pariwisata Dinas Pariwisata Kota Batu)," $J$. Pengemb. Teknol. Inf. dan Ilmu Komput. Univ. Brawijaya, vol. 2, no. 12, pp. 6475-6484, 2018.

[19] A. T. Helmi, I. Aknuranda, and M. C. Saputra, "Analisis Dan Pemodelan Proses Bisnis Menggunakan Business Process Improvement (BPI) Pada Lembaga Bimbingan Belajar (Studi Kasus: Lembaga Bimbingan Belajar Prisma)," J. Pengemb. Teknol. Inf. dan Ilmu Komput. Univ. Brawijaya, vol. 2, no. 10, 2018.

[20] R. Y. L. Hende, N. Y. Setiawan, and Y. T. Mursityo, "Perancangan Perbaikan Bisnis Proses Menggunakan Metode Business Process Improvement Pada Layanan Penerbitan Majalah," $J$. Pengemb. Teknol. Inf. dan Ilmu Komput., vol. 2, no. 3, pp. 1328-1336, 2018. 